\title{
Analysis of Biology Teacher's Understanding in Lebak Regency Towards Environmental Literacy Based on Teaching Experience
}

\author{
Ami Aviatin Avivi ${ }^{1, *}$ Paidi $^{2}$ \\ ${ }^{1}$ Master of Biology Education, Faculty of Mathematics and Natural Sciences, Universitas Negeri Yogyakarta, \\ Indonesia \\ ${ }^{2}$ Department of Biology Education, Faculty of Mathematics and Natural Sciences, Universitas Negeri Yogyakarta, \\ Indonesia \\ *Corresponding author. Email: amiaviatin.2019@student.uny.ac.id
}

\begin{abstract}
This research was conducted to find out about understanding of biology teachers in Lebak Regency towards environmental literacy based on teaching experience. This research are using survey method with descriptive analysis. This research was conducted from May to September with research subject were 40 teachers of Public Senior High School/Islamic Senior High School (SMAN/MAN) in Lebak Regency. Data were obtained using test technique. The test consists of multiple choice questions along with reason in total 20 questions related to the understanding of environmental literacy. The results of the research indicate that: (1) biology teachers in Lebak Regency have high understanding about environmental literacy with the average score of 62. (2) There is a difference of understanding among teachers towards environmental literacy based on teaching experience. Teachers on 21 years above have lower score compared to the teachers with tenure of 1 until 10 years and 11 until 20 years.
\end{abstract}

Keywords: Teacher understanding, Environmental literacy, Teaching experience

\section{INTRODUCTION}

Environmental problems that occur nowadays have become issues that are getting a lot of attention. Environmental problem in global or national scope mostly happened because of human behavior [1]. One of the environmental problems that happened in Lebak Regency is flood. Not only the rainfall, the land cover/the use of the forest to be a plantation by the community is also become the reason why flooding happened. Besides flood, the avalanche also happens several times in Lebak Regency. Same as the flood, avalanche is not solely happened because of nature phenomenon. The avalanche that happened cannot be separated from human's doing which illegally established gold mining causes opening slopes without vegetation [2].

Environmental problems that occur cannot be solved only by improving nature alone. Human consciousness to preserve the environment as important as to preserve the continuity of the human being itself [3]. Individual's behavior to the environment is representing their environmental literacy [4]. Environmental literacy could be interpreted as a knowledge about environment and one's attitude that used to make an effective decision in all contexts of environment [5]. The solution to resolve the environmental problem is developing a community that has environmental literacy and more responsible behavior towards environment [6].

Students are one of the elements of community and adolescent who has potential resource in the future time and later on will go into community [1]. As a heirs in community, students really need to have environmental literacy skills to always maintain, manage, be responsible, and preserve the environmental so that an environmentally literate generation is formed. Environmental education is necessarily needed as to build the consciousness of the environment by making positive changes in 
knowledge, attitude, and individual behavior towards environment [7]. Environmental education is a medium to develop environmental literacy [4].

The competence of one's environmental literacy could be measured through four components that are: environmental knowledge, dispositions, competencies, and environmentally responsible behavior [8]. The weak of environmental literacy in Indonesia's students one of them happened in Lebak Regency, it could be seen based on the result of 2019 national exam's (UN) score on the subject environmental change that is 33,68 [9], the score on this subject could be said as low score. Based on those data then the level of environmental literacy needs to be improved [10].

Teacher as the important pillar in learning process, take part in the development of environmental literacy level of students [11]. Moreover, a teacher also has function as a role model to change the education and society so that it would create a future continuity [4]. A teacher also demanded to comprehend or understand to what he/she is teaching, and knowing what he/she is communicating. Understanding of educational insights and foundations, mastery of learning design, mastery of learning implementation and mastery of student learning outcomes assessment are indicators of teaching professionalism [12]. The lack of teacher understanding about characteristics that had taught and ignorance of the teacher about the essence of the knowledge field could be a failure factor of learning purpose accomplishment [13]. Accordingly, the understanding of environmental literacy is necessarily owned by teachers in order to help students to be environmentally literate.

One of the variables that could affect the level of teacher understanding is teaching experience. Teachers who having years of teaching experience will improve teaching skills, the higher the level of understanding and the higher the ability to carry out their duties as a teacher [14]. The more experience in teaching, the higher level of self-efficacy to manage the class [15], experience basis and skills [16]. Teacher who has more experience in teaching, possessing a better skills to teach something, and vice versa. Furthermore, a teacher with wider experience in teaching has pedagogy and better content of knowledge, rather than a teacher who has less experience in teaching [17].

However, after conducted a literature analyzing it could not be found a research about Biology teacher's understanding in Lebak regency, Banten province towards environmental literacy in terms of teaching experience. Based on that reason, this research is crucial to be done to see how far the understanding of Biology teacher in Lebak Regency towards environmental literacy based on teaching experience.

\section{METHOD OF RESEARCH}

\subsection{Research Design}

Overall, this research is using survey method. Whose population in this research follows the principle of Daniel's hypothetical population [18]. In this research, a representative sample was used to narrow the scope of the study and the sampling technique was used convenience sampling technique, namely the current sample, which consisted of 40 teacher biology of Public Senior High School/Islamic Senior High School (SMAN/MAN), who were active and willing to be respondents in this research. Convenience sampling is a type of non-random sampling in which members of the population meet certain criteria such as easy reach, geographic proximity, time availability, and are willing to participate in following the studi objectives [19]. Besides convenience sampling also refers to research subjects from the population that are easy to find by researcher [20]. The data collected is based on teaching experience. This research was conducted in Lebak Regency on April-September 2020.

\subsection{Data Collection}

Collected data using test technique with a closed instrument. The instrument of this research using 7 dimensions of understanding according to Bloom's taxonomy those includes interpreting, exemplify, classifying, summarizing, concluding, comparing, and explaining [21]. Then, it is expanded into 20 multiple choice written test. The questions are categorized into 4 components which encompass the understandings of environmental knowledge (7 questions), understanding dispositions (5 questions), understanding competencies (4 questions), and understanding environmentally responsible behavior (4 questions). The instruments in this research had tested first to ensure its validity and reliability. The validity test was carried out using face validity and the reliability test was carried out using the KR 20 formula analyzed with SPSS.

\subsection{Data Analysis}

This research is using quantitative descriptive analysis. The data is analyzed by calculating the average score based evaluation on every answers from the respondents then the data which had gathered 
categorized based on the table below [22] and interpreted into descriptive and narrative form.

Table 1. Understanding criteria

\begin{tabular}{|c|c|}
\hline Score & Criteria \\
\hline$X \leq 25$ & Very low \\
\hline $25<X \leq 41.65$ & Low \\
\hline $41.65<X \leq 58.35$ & Moderate \\
\hline $58.35<X \leq 75$ & High \\
\hline $75<X$ & Very high \\
\hline
\end{tabular}

\section{RESULTS AND DISCUSSION}

\subsection{Biology teacher's understanding of environmental literacy}

The data of Biology teacher's understanding of environmental literacy obtainable after doing a test which consists of 20 multiple choice written test. Here are the following table 2 which shows the result of teacher's understanding measurement towards environmental literacy.

Based on table 2, the teachers having an average score of 62 , with a minimum score of 30 , maximum score of 80, and standard deviation of 8.883. If it seen by the obtainable average score means that teacher's understanding measurement towards environmental literacy is a high classification. Teachers are one of the determinants of a successful implementation school learning process. Teacher's quality and effectiveness are probably depending on their knowledge and pedagogy's intelligence [11]. Teacher's understanding is important to be able to improve the educational process because teachers are closely related with how to establish students learning environment, influence students' motivation, and managing classroom [23]. environmental knowledge, (2) dispositions, (3) competencies, and (4) environmentally responsible behavior. So that, they are acquire a measurement result as in table 3 .

The table 3 shows measurement of biology teacher's understanding of environmental literacy by the environmental knowledge component are obtained the average score of 51.74 which appertain into medium criteria. Environmental literacy consists of five environmental knowledge that are physical system knowledge and ecology, social system knowledge, culture and politic, the knowledge of current issue which relate to the environment, and participation knowledge of society in the form of action [5]. Environmental knowledge is used to respond or solve the environmental problems.

The result of biology teacher's understanding of environmental literacy by dispositions appertain into medium criteria with an average score is 56.5. Whereas, in competencies and environmental responsible behavior, teacher's understanding obtained an average score result of 78.75 and 66.87 both appertain into a very high and high criterion. Dispositions are important determinants of behaviors to impose positive or negative towards environment. Which consists of a sensitiveness to the environment, attitudes, concerns and worldview, personal responsibility to the environment, self- efficacy, motivation and intention to step in. Competition means an aggregate of skills and abilities expressed in real life which has a specific purposes. Generally, a competent person who is able doing things with certain quality and accuracy by many times [5]. Enviromentally responsible behavior is a learning experience that produces new behaviors. [5] By various enough experiences are able to be a habit, then it outcomes of many expressions intentional behavior.

\subsection{Biology Teacher's Understanding of Environmental Literacy Based on The Components}

Teacher's understanding of environmental literacy categorized into 4 components which are (1)

Table 2. Understanding of environmental literacy of biology teachers

\begin{tabular}{|c|c|c|c|c|c|c|}
\hline \multirow{2}{*}{} & \multirow{2}{*}{$\mathbf{N}$} & \multicolumn{2}{|c|}{ Understanding score of biology teachers } & \multirow{2}{*}{ Criteria } \\
\cline { 3 - 6 } & & Mean & Min & Max & $\begin{array}{c}\text { Sd. } \\
\text { Deviation }\end{array}$ & \\
\hline Biology teacher & 40 & 62 & 30 & 80 & 8.883 & high \\
\hline
\end{tabular}


Table 3. Biology teachers understanding of environmental literacy based on components

\begin{tabular}{|l|c|c|c|c|l|}
\hline \multirow{2}{*}{$\begin{array}{l}\text { Componets of } \\
\text { environmental literacy }\end{array}$} & \multicolumn{2}{|c|}{ Understanding score of biology teacher } & \multirow{2}{*}{ Criteria } \\
\cline { 2 - 6 } & Mean & Min & \multicolumn{1}{l}{ Max } & Sd. Deviation & \\
\hline Environmental knowledge & 51.74 & 10 & 85 & 15.133 & Moderate \\
\hline Dispositions & 56.5 & 40 & 80 & 13.502 & Moderate \\
\hline Competencies responsible & 78.75 & 50 & 100 & 14.489 & Very high \\
\hline $\begin{array}{l}\text { Environmentally } \\
\text { behavior }\end{array}$ & 66.87 & 25 & 100 & 15.387 & High \\
\hline
\end{tabular}

Table 4. Biology teachers understanding of environmental literacy based on teaching experience

\begin{tabular}{|c|c|c|c|c|c|c|}
\hline \multirow[t]{2}{*}{ Teaching experience } & \multirow[t]{2}{*}{$\mathrm{N}$} & \multicolumn{4}{|c|}{ Understanding score of biology teachers } & \multirow[t]{2}{*}{ Criteria } \\
\hline & & Mean & Min & Max & $\begin{array}{l}\text { Sd. } \\
\text { Deviation }\end{array}$ & \\
\hline $1-10$ years & 24 & 60 & 30 & 65 & 8.905 & high \\
\hline $11-20$ years & 10 & 69 & 60 & 80 & 6.687 & high \\
\hline 21 years above & 6 & 57 & 50 & 70 & 6.055 & moderate \\
\hline
\end{tabular}

\subsection{Biology Teacher's Understanding of Environmental Literacy Based on The Components}

According to statistic descriptive calculation that has conducted, there are some groups of teaching experience, the group 1 is consist of teachers who have 1 to 10 years of teaching experience; group 2 consist of teachers who have 11 to 20 years of teaching experience; and group 3 consist of teacher who have 21 years and above of teaching experience as in the table 4.

Based on the table 4 biology teacher's understanding of environmental literacy by teacher's tenure has a result that biology teacher of group 1 with 1 to 10 years teaching experience amount 24 people gets an average score of 60 which means they have a high understanding of environmental literacy. Likewise, biology teachers who were included in group 2 who had 11-20 years of teaching experience totaling 10 teachers had an average score of 69 . Whereas, group 3 of biology teacher's with teaching experience 21 years and over totaled 6 teachers who had an average score 57.

There are differences in biology teacher's understanding of environmental literacy based on teaching experience. Biology teacher's who have 11 to 20 years of teaching experience have the highest average score. Meanwhile, teachers who have teaching experience of 21 years and over get the lowest average score. This happened maybe because of fatigue, a lot of experience during work. Moalosi [24] in his study found years of teaching experience can affect the effectiveness of teachers in engaging students and teaching strategies because they can become less motivated due to years of service that lead to fatigue. One explanation related to the disappearance of idealism and fatigue enhancement may be because loads of years teaching experience [25]. Meanwhile, teachers in the early years of work are usually more enthusiastic in developing their understanding and knowledge.

Beginner teachers are very enthusiastic about their profession in the early years and try to develop the knowledge and understanding and skills of their students [26]. In the 8 to 23 years of teacher will experiencing an improvement motivation and commitment. While teachers will experiencing of decreased motivation in the 24 years above of teaching experience [27]. Another factor that can affect teacher understanding is the amount of information obtained during work. Information can be obtained by teachers from various print and electronic sources. In this case, in accordance with the demands of $21^{\text {st }}$ century education teachers need to have digital literacy. This can be used to support increased understanding and teacher performance in the learning process. 
Digital literacy can support and support teachers to seek planning and preparation of learning programs so that they can foster relevant competencies in students [28]. School administration is also become one of the obstacle factors of how works the environmental education and put down the enthusiasm along with commitment for the environmental education among teachers [25]. If there are teachers with excellent knowledge and understanding but that knowledge shrinks over time, the factor that can explain this is the condition of the school in which the teachers are located [29].

\section{CONCLUSION}

According to the analysis research result of understanding biology teacher in Lebak Regency on environmental literacy based on teaching experience, it can be concluded that in generally biology teachers in Lebak Regency have a high understanding of environmental literacy with the average score of 62 . In addition, there are differences in biology teachers' understanding of environmental literacy based on teaching experience. Those aged 21 years and over had an average score of 57 lower when compared to teachers who had teaching experience between 1 and 10 years who had an average score of 60 and 11 to 20 years with an average score of 69.

\section{ACKNOWLEDGMENTS}

The author would like to thank to Allah SWT, and than like thank to Yogyakarta State University, the biology teacher of public senior high school/Islamic senior high school (SMAN/MAN) ini Lebak Regency, and my family for their support and asistence during the research process.

\section{REFERENCES}

[1] Barkatin, L. Syaufina, H. Wijayanto, Analisis Perilaku Pelajar terhadap Lingkungan Studi Kasus Pendidikan Menengah di Kabupaten Bogor, Jurnal Pengelolaan Sumberdaya Alam dan Lingkungan 6 (2016) 122-130. DOI: https://doi.org/10.19081/jps1.6.2.122

[2] M-K. Soleman, F. Nurcahyani, S.L. Munajati, Pemetaan Multirawan Bencana di Provinsi Banten, Globe Ilmiah 14 (2012) 46-59.

[3] M. Erdogan, A. Ok, An Assessment of Turkish Young Pupils' Environmental Literacy: A Nationwide Survey, International Journal of Science Education 33 (2011) 2375-2406. DOI: https://doi.org/10.1080/09500693.2010.550653
[4] D. Goldman, B. Yavetz, S. Pe'er, Student Teachers' Attainment of Environmental Literacy in Relation to Their Disciplinary Major During Undergraduate Studies, International Journal of Environmental and Science Education 9 (2014) 369-383.

DOI: https://doi.org/10.12973/ijese.2014.222a

[5] K. Hollweg, J. Taylor, R. Bybee, T. Marcinkowski, W. McBeth, P. Zoido, Developing A Framework for Assessing Environmental Literacy, North American Association for Environmental Education (NAAEE), 2011.

[6] S. Ozsoy, H. Ertepinar, N. Saglam, Can ecoSchools Improve Elementary School Students' Environmental Literacy Levels?, Asia-Pacific Forum Science Learning and Teaching, vol. 13, 2012

[7] A.K. Liefländer, F.X. Bogner, Educational Impact on The Relationship of Environmental Knowledge and Attitudes, Environmental Education. Research 24 (2018) 611624.DOI:https://doi.org/10.1080/13504622.2016 .1188265

[8] W. McBeth, T.L. Volk, The National Environmental Literacy Project: A Baseline Study f Middle Grade Students in The United States, Journoal Environmental Education 41 (2009) 55-67. DOI: https://doi.org/10.1080/00958960903210031

[9] Kementrian Pendidikan dan Kebudayaan, Laporan hasil ujian nasional, Pusat Penilaian Pendidikan, 2019, Accessed on: Sept. 2020, [Online]. Available: https://hasilun.puspendik.kemdikbud.go.id/

[10] R. Nasution, Analisis kemampuan literasi lingkungan siswa SMA kelas X di Samboja dalam pembelajaran biologi, in: Biologi, Sains, Lingkungan, dan Pembelajaran, in: Proceeding Biology Education Conference, vol. 13, Universitas Sebelas Maret, Surakarta, 2016, pp. 352-358.

[11] P-M. Sadler, G. Sonnert, H.P. Coyle, N. CookSmith, J.L. Miller, The Influence of Teachers' Knowledge on Student Learning in Middle School Physical Science Classrooms, American Education Research Journal 50 (2013) 10201049.

DOI: 
[12] R. Nurutami, A. Adman, Kompetensi Profesional Guru sebagai Determinan terhadap Minat Belajar Siswa, Jurnal. Pendidikan Manajemen Perkantoran 1 (2016) 119. DOI: https://doi.org/10.17509/jpm.v1i1.3345

[13] S. Sudarisman, Memahami Hakikat dan Karakteristik Pembelajaran Biologi dalam Upaya Menjawab Tantangan Abad 21 Serta Optimalisasi Implementasi Kurikulum 2013, Florea Jurnal Biolgi dan Pembelajaran 2 (2015) 29-35.

DOI: https://doi.org/10.25273/florea.v2i1.403

[14] M. Lena, Pengaruh Masa Kerja dan Sertifikasi Guru terhadap Komitmen Kerja Guru SMA, Jurnal Serambi Ilmu 7 (2014) 56-61

[15] S.M. Putman, Investigating Teacher Efficacy: Comparing Preservice and Inservice Teachers with Different Levels of Experience, Action Teacher Education, Routledge., vol. 34, 2012, pp. 26-40.

DOI: https://doi.org/10.1080/01626620.2012.642285

[16] M.I. Rahida Aini, A. Rozita, A. Zakaria, Can Teachers' Age and Experience Influence Teacher Effectiveness in HOTS?, International. Journal of Advanced Studies in Social Science and Innovation 2 (2018) 144-158. DOI: https://doi.org/10.30690/ijassi.21.11

[17] M.K. Antony, Paidi, B. Subali, S. P. Pradana, N. Hapsari, F. E. C. Astuti, Teacher's TPACK Profile: The Affect of Teacher Qualification and Teaching Experience, in: Journal Physics Conference Series, vol. 1397, Elsevier, Amsterdam, 2019, p. 012054. DOI: https://doi.org/10.1088/17426596/1397/1/01205 $\underline{4}$

[18] R. Streitberg, W-W. Daniel, Applied Nonparametric Statistics, Biometrics, Jstor, 1991, DOI: https://doi.org/10.2307/2532422

[19] I. Etikan, Comparison of Convenience Sampling and Purposive Sampling, American Journal Theoretical and Applied Statistics 5 (2016) 1. DOI: https://doi.org/10.11648/j.ajtas.20160501.11

[20] L. M. Given, The Sage Encyclopedia of Qualitative Research Methods, Sage publications, 2008.
[21] L.W. Anderson, D.R. Krathwohl, A Taxonomy for Learning Teaching and Assessing A Revision of Bloom`s Taxonomy Of Educational Objetives, Longman, 2001.

[22] P. Paidi, I.S. Mercuriani, B. Subali, Students' Competence in Cognitive Process and Knowledge in Biology Based on Curriculum Used in Indonesia, International. Journal. Instruction 13 (2020) 491-510. DOI: https://doi.org/10.29333/iji.2020.13334a

[23] Z. Ünal, A. Ünal, The Impact of Years of Teaching Experience on The Classroom Management Approaches of Elementary School Teachers, International Journal of Instruction 5 (2012) 41-60

[24] S.W.T. Moalosi, Teachers' Self Efficacy: is Reporting, Journal of International Education Research 9 (2013) 397-406

[25] K.T. Stevenson, M.N. Peterson, H.D. Bondell, A.G. Mertig, S.E. Moore, Environmental, Institutional, and Demographic Predictors of Environmental Literacy among Middle School Children, PLoS One 8 (2013) 1-11. DOI: https://doi.org/10.1371/journal.pone.0059519

[26] M. Çakmak, Learning from Teaching Experiences: Novice Teachers ' Thoughts*, Hacettepe Üniversitesi Eğitim Fakültesi Dergisi. (H. U. Journal Education) 1 (2013) 55-66.

[27] R.M. Klassen, V.M.C. Tze, S.M. Betts, K.A. Gordon, Teacher Efficacy Research 1998-2009: Signs of Progress or Unfulfilled Promise?, Educational Psychology Review, Springer, vol. 23, 2011, pp. 21-43. DOI: https://doi.org/10.1007/s10648-010-9141-8

[28] G. Falloon, From Digital Literacy To Digital Competence: The Teacher Digital Competency (TDC) Framework, Educational Technology Research and Development 68 (2020) 24492472. DOI: https://doi.org/10.1007/s11423-02009767-4

[29] S. Donkoh, Investigating The Effect of Teaching Experience on Teacher Knowledge, International Journal of Scientific and Research Publications 7 (2017) 319-327. DOI: https://doi.org/10.1007/978-94-007-2150$\underline{0 \_100714}$ 